\title{
Medkulturna problematika vzhodnoazijskih študij ter vprašanje tradicije in modernosti
}

\author{
Jana S. ROŠKER*
}

\section{Izvleček}

Članek raziskuje in predstavlja nekatere osrednje probleme, ki so povezani z raziskavami znotraj azijskih študij. Avtorica najprej prikaže, zakaj je za medkulturno bolj ozaveščeno raziskovanje vzhodnoazijskih regij pomembno, da se tem kulturno-jezikovnim krogom približujemo skozi optiko njihovih matičnih jezikov in pisav. Uporaba primarnih virov v matičnih jezikih omogoča vpogled $\mathrm{v}$ strukturo vprašanj in interpretacij, ki so lastna socializacijskim, vsebinskim in metodičnim izhodiščem družb, katere tvorijo predmet raziskav. Skozi optiko tovrstnih metodoloških vprašanj se članek v vsebinskem pogledu osredotoča na osrednje probleme azijskih modernizacij in na vprašanja o tem, ali jih $\mathrm{v}$ resnici lahko enačimo s pozahodnjenjem. Avtorica ugotavlja, da je modernizacija proces, ki vključuje tako univerzalne kot kulturno opredeljene elemente.

Ključne besede: azijske študije, modernizacija, medkulturne raziskave

\begin{abstract}
The article explores and introduces some of the crucial problems linked to Asian studies, from the viewpoint of intercultural methodology. The author explains why the mastering of Asian languages in the research process is of central importance, for it allows us, among other things, to apply and incorporate into the research original, primary sources from these regions. Through the lens of such methodological issues, the article then explores some central problems of Asian modernization and the question of whether this can really be equated with Westernization. The author concludes that modernization is a process, which includes universal, as well as culturally determined elements.
\end{abstract}

Keywords: Asian studies, modernization, intercultural research

Jana S. ROŠKER, Profesorica, Oddelek za azijske študije, Univerza v Ljubljani, Slovenia. jana.rosker[at]ff.uni-lj.si 


\section{Uvod}

Prva stvar, ki jo velja razčistiti v splošni zmedi, ki vlada v javnosti, ko je govor o vzhodnoazijskih študijah, ${ }^{1}$ je dejstvo, da ne gre za jezikoslovne discipline, torej za znanosti, ki naj bi se osredotočale samo na lingvistično raziskovanje vzhodnoazijskih jezikov, njihovih funkcij in struktur. Gre za kulturološke stroke, ki bolj ali manj celostno obravnavajo geopolitični prostor kitajskega, japonskega ali korejskega kulturno-jezikovnega kroga. V sklopu študija teh disciplin pa je seveda najprej treba obvladati jezike in pisave teh regij, ki tvorijo eno temeljnih orodij za zbiranje pristnejših informacij o obravnavanih kulturah in civilizacijah. To je znanje, ki nam ga poleg zahodne literature, ki obravnava različne vidike Vzhodne Azije, nudijo tudi in predvsem primarni - torej sami kitajski, japonski in korejski - viri.

Kot vsaka pionirska doba sta bili tudi prvi desetletji razvoja teh disciplin v Sloveniji opredeljeni $\mathrm{z}$ nujo pridobivanja, sestave oziroma izdelave osnovnega vsebinskega in metodološkega orodja, ki je nujno za neoporečno delovanje njenih kategorialnih in terminoloških aparatov. Zadnji stavek se morda sliši nekoliko mehanistično in bi zato znal biti tudi zavajajoč. Če vam ne bomo predstavili še druge plati te tehnicistično opisane medalje, boste ob branju tovrstnih opisov dobili občutek, da so vzhodnoazijske študije kot del humanističnih in družboslovnih znanosti nekakšen stroj, ki ga je treba hraniti z zadostno količino preverjenih in večplastnih informacij o obravnavanih regijah, da bo nato izbljuval kopico uporabnih, zanimivih in družbeno relevantnih rezultatov.

In vendar predstavljajo te vede - tako kot večina znanstvenih disciplin, če se le hočemo nanje ozreti $z$ vidika občečloveške radovednosti, interaktivnosti in želje po spoznanju - mnogo več od tega. Posebnost teh kulturoloških disciplin je v tem, da temeljijo na spoznavanju matičnih jezikov, torej kitajščine, japonščine in korejščine. Poznavanje in obvladovanje teh jezikov je namreč predpogoj za prepoznavanje specifičnih, jezikovno in kulturno pogojenih konceptualnih in kategorialnih aparatov ter strukturnih vzorcev mišljenja in interpretacije, ki so se izoblikovali v vzhodnoazijski tradiciji. Tovrstno raziskovanje je seveda povezano s sposobnostjo premostitve tradicionalnih evropskih semantičnih kriterijev. Ta pa vključuje tudi iskanje sistematike razumevanja in posredovanja, temelječe na epistemoloških osnovah, ki so drugačne od diskurzov, kakršni so se oblikovali v sklopu evropske kulturne tradicije.

$\mathrm{Na}$ osnovi razjasnitve tovrstnih metodoloških problemov bomo v tem članku poskušali osvetliti tudi problem specifike vzhodnoazijske modernizacije, predvsem

1 Pri tem gre predvsem za sinološke, japonske in korejske študije. 
glede vprašanja o tem, ali je modernizacija v resnici zgolj proces, ki je bil v Vzhodno Azijo uvožen iz Evrope, ali pa gre pri vzhodnoazijski inačici za proces, ki ni zgolj univerzalne narave, temveč vsebuje tudi specifične kulturno pogojene elemente.

\section{Temeljna metodološka vprašanja}

Vsekakor tudi takšno preučevanje še vedno izhaja iz premis tradicionalnega evropskega družboslovja in humanistike. Toda njegov osrednji motiv ni zgolj v spoznavanju nekakšnih »tujih kultur«, ampak tudi v relativizaciji sistemov vrednot in struktur dojemanja. Temeljni motiv preučevanja specifike vzhodnoazijskih tradicij in sodobnih vzhodnoazijskih družb konec koncev večinoma še vedno izhaja iz premis tradicionalne evropske družboslovne in humanistične znanosti, torej ni zgolj v spoznavanju nekakšnega »drugačnega modela teorije«, temveč v relativizaciji sistemov vrednot in struktur dojemanja. Ta relativizacija pogojuje vsakršen uvid v notranjo in konceptualno zaključenost konkretnih zgodovinskih, ekonomskih, političnih in kulturnih sklopov, ki tvorijo materialne in idejne temelje vzhodnoazijskih družbenih stvarnosti, hkrati pa iz tovrstnih uvidov tudi logično izhaja. Takšni splošni uvidi so torej predpogoj za vsakršno resnično medkulturno študijo. Dokopavanje do takšnih, na relativizaciji vrednot, semantičnih in kognitivnih struktur temelječih uvidov pa zahteva ne samo veliko časa in potrpljenja, temveč predvsem dobršno mero rahločutnosti. Le na tak način smemo upati, da v soočanju $\mathrm{z}$ vzhodnoazijskimi kulturnimi tradicijami ne bomo samo strumno korakali po poti najsmotrnejše racionalnosti in se počasi, a zanesljivo spremenili v strokovnjake in strokovnjakinje brez duha, ampak da bomo nekoč resnično lahko dokazali sposobnost, ki je v tem pogledu morda najpomembnejša: sposobnost neobremenjenega učenja.

Soočanje $\mathrm{z}$ vzhodnoazijskimi kulturami, njihovo dojemanje in razumevanje je namreč pogosto povezano s problematiko različnih jezikov, tradicij, zgodovin in socializacij. Zato so interpretacije različnih elementov in vidikov teh kultur nujno povezane $\mathrm{z}$ geografsko, politično in ekonomsko pozicijo subjekta, ki jih interpretira, pa tudi objekta, ki ga ta subjekt interpretira. Zato ni naključje, da slovenske raziskave vzhodnoazijskih regij vselej nujno vključujejo problematiko prevajanja. Pri tem ne gre samo za jezikovno, ampak tudi za diskurzivno prevajanje, ki vključuje tolmačenje besedilnih in govornih struktur, kategorij, konceptov in tudi vrednot $\mathrm{v}$ različnih socio-kulturnih kontekstih. $\mathrm{V}$ tem postopku prihaja namreč precej pogosto do razlike med enakim etimološko - normativnim pojmovanjem določenega izraza na eni in včasih popolnoma različnim dojemanjem istega izraza na nivoju splošnega, družbeno veljavnega socialnega konteksta v obravnavanih 
družbah na drugi strani. Kot zelo nazoren primer lahko tukaj navedem, denimo, pojem avtonomije in njegov kitajski prevod zilü 自律. Raziskava, ki sem jo o teh dveh pojmih opravila na Tajvanu, je tako vsebovala filološko analizo ter tudi primerjalne ankete; njeni rezultati so jasno in nedvoumno pokazali, da se ta pojma, ki imata popolnoma enak etimološki pomen in katerih konotacije se $\mathrm{v}$ filozofskih diskurzih popolnoma pokrivajo, $v$ kitajskih in evropskih družbah dojemata kontradiktorno. Medtem ko smo mi vajeni pojem avtonomije asociirati s svobodo, neodvisnostjo in samostojnostjo, se isti pojem $\mathrm{v}$ kitajskem prevodu dojema kot samorestrikcija, samodisciplina in kot nadzor samega sebe (prim. Rošker 2006, 220).

Tovrstna metodološka znanja temelje tako na filoloških kot tudi na filozofskih osnovah. Zakaj filozofija je tista, ki v vsaki kulturi in v vsakem jeziku zakoliči konceptualizacijo realnosti, in tista, ki zasnuje kategorialni aparat, ki nam - preko ustreznega filološkega znanja - omogoča razumevanje in interpretacijo konceptualnega ogrodja, $v$ katerega so vpeti posamični jeziki in v katerega omrežju rastejo različne kulture.

\section{Osrednja filozofska vprašanja in posebnosti vzhodnoazijskih konceptov in kategorij}

Pri raziskavah klasičnih filozofij vzhodnoazijskih regij pa gre poleg tega tudi za problematiko dojemanja in posredovanja tradicionalnih vsebin, ki so tako $\mathrm{v}$ govorici kot $\mathrm{v}$ besedilih strukturirana na osnovi različnih slovničnih in semantičnih ustrojev. Premise, na katerih temelji sodobna znanost, ter metodološki postopki, ki izhajajo iz njih, so po svojem bistvu še vedno del splošno veljavnih postopkov zahodne (zlasti evropske) tradicije. Tlačenje popolnoma drugače strukturiranih vidikov različnih (torej t. i. ne-evropskih) stvarnosti v kalupe tovrstnih formalnih predpisov nas lahko privede v slepo ulico nerazumevanja, ali, še huje, popolnoma napačnega razumevanja preučevane resničnosti. In vendar se moramo teh postopkov držati, če hočemo zares nekaj povedati o izsledkih naših študij in če hočemo pri tem ostati razumljivi. Medkulturne raziskave torej na vsak način vključujejo problematiko prevajanja; kot smo že omenili, pri tem ne gre zgolj za jezikovno, temveč tudi za diskurzivno prevajanje, ki vključuje tolmačenje posamičnih besedilnih in govornih struktur, kategorij, konceptov in vrednot $\mathrm{v}$ različnih sociokulturnih kontekstih. $V$ tem okviru se zelo jasno pokaže potreba po revitalizaciji klasičnih kategorij in konceptov tradicionalnih vzhodnoazijskih filozofij. Ta naloga zahteva medkulturno relativizacijo vsebin, ki mora temeljiti na metodoloških pristopih, ti pa ustrezati specifiki proučevanja vzhodnoazijske idejne tradicije in 
primerjalne filozofije oziroma kulturologije. Tovrstni pristop je osredotočen na celovito ohranjanje njihovih posebnosti in na ohranjanje ter nadaljevanje avtohtonih tradicionalnih metodoloških načel. To pa seveda nikakor ne pomeni negacije potrebe po soočanju z zahodno (in globalno) filozofijo. Svetovna (še posebej evropska in indijska) filozofija vsekakor vsebuje veliko elementov, ki jih v vzhodnoazijski tradiciji ne najdemo. Raziskovanje in uporaba teh elementov ni nujna samo kot dragoceno orodje oplajanja novih idejnih sistemov; komparativni vidik je pomemben tudi in predvsem za boljše razumevanje lastne tradicije. Vendar velja pri tem, kot je zapisal moderni kitajski teoretik znanosti Zhang Dainian, paziti na to, da se izognemo uporabi nesoizmerljivih (inkomensurabilnih) metod, ki se preučevanja kitajske zgodovine lotevajo skozi optiko zahodnih konceptov in kategorij: »Različne filozofske teorije uporabljajo različne koncepte in kategorije. Koncepti in kategorije, katere uporabljajo filozofske teorije različnih narodov, pa se med seboj še bolj razlikujejo. «² (Zhang 2003,118)

Vzhodnoazijske filozofije se namreč že po osnovi razlikujejo od evropske ali indijske filozofije. Če torej želimo postaviti novo sistematiko vzhodnoazijske idejne tradicije, moramo najprej poznati njene lastne, paradigmatske posebnosti. Če jo bomo namreč želeli sistematizirati $\mathrm{z}$ uporabo evropskih ali indijskih kriterijev, se bo njeno subtilno bistvo nujno izmaknilo našemu razumevanju.

Seveda pa pri metodoloških problemih, na katere moramo biti pozorni pri obravnavanju vzhodnoazijskih kultur, njihovih ideologij in miselnosti, nikakor ne gre zgolj za probleme filozofsko-konceptualne narave. $V$ tem smislu je prav tako pomemben geopolitični vidik naših razprav; pri analizi sporočilnosti vsake družbeno relevantne idejne struje je namreč pomembno upoštevati tudi ekonomski in zgodovinski kontekst, znotraj katerega se je razvila.

Vzhodnoazijske študije v prvi vrsti temeljijo na želji po polilogih, ki naj bi evropske družbe povezovali $\mathrm{z}$ vzhodnoazijskimi, zato so $\mathrm{v}$ središču njihovih interesov seveda sodobne, modernizirane vzhodnoazijske družbe. Vendar pri tem ne smemo pozabiti, da predstavlja historizacija njihovih tradicij osnovo za koherentno razumevanje njihovih globaliziranih modernosti.

\section{Problematika modernizacije}

Samo od sebe se nam zastavi vprašanje, na kakšen način vrednotiti modernizacijo vzhodnoazijskih regij, ki naj bi temeljila na tranziciji med tradicionalnimi in sodobnimi kulturnimi parametri. Vzhodnoazijska modernizacija je bila vsekakor

2 不同的哲學理論包涵不同的概念, 範疇. 不同的民族的哲學理論, 更是具有不同的概念, 範疇 
pogojena s stiki z zahodnimi kolonialnimi silami. Zato je zahodna kolonializacija gotovo merodajno vplivala na začetek, pa tudi na potek modernizacije vzhodnoazijskih družb. Ampak - ali lahko zaradi tega vzhodnoazijsko modernizacijo enačimo s pozahodnjenjem vzhodnoazijskih regij? Veliko bolj razumna je predpostavka, po kateri je modernizacija vselej kompleksen pojav, ki ga sestavljajo tako univerzalni kot tudi kulturno pogojeni elementi.

Klasične definicije modernizacije, ki jih je zasnoval že Hegel, ${ }^{3}$ jih kasneje v svojih socio-ekonomskih teorijah poglobil Marx (2012), podrobneje pa so jih kasneje opredelili Weber (1989), zgodnji Lukàcs (1986) in starejši predstavniki Frankfurtske šole, ${ }^{4}$ izhajajo iz predpostavke, po kateri v Vzhodni Aziji ni moglo priti do modernizacije, kajti razvoj njenih tehnologij nikoli ni dosegel ravni, ki bi lahko omogočila industrijsko revolucijo. Raziskave, ki so privedle do teorije, $\mathrm{v}$ zahodni sinologiji znane pod imenom "zametki kitajskega kapitalizma« (Zhongguo zibenzhuyi mengya), nazorno kažejo, da so bila proizvodna sredstva na Kitajskem že v 12. stoletju na dovolj visoki stopnji razvoja, da bi tam lahko prišlo do industrijske revolucije. Vzroki za dejstvo, da do nje ni prišlo, tičijo v posebnostih politično-ekonomskega ustroja tradicionalne Kitajske. Ta je bil namreč intra-sistemski, kar pomeni, da je spodbujal predvsem stabilnost in centralizacijo lokalnih skupnosti. Ideološko gledano je bil ta sistem podprt $\mathrm{z}$ idejnim sistemom, $\mathrm{v}$ katerem preteklost ni bila zgolj merodajna za vrednotenje sedanjosti, ampak je predstavljala tudi kažipot na poti v prihodnost. Eden od nadaljnjih razlogov za odsotnost industrijske revolucije je bil tudi v tem, da Kitajska - drugače od Evrope - v tem ključnem trenutku tehnološkega razvoja ni bila soočena $z$ ekonomsko krizo.

Zato pa je bila Kitajska (in na nekoliko drugačen način vsa Vzhodna Azija) soočena $\mathrm{z}$ globoko in vseobsežno krizo od pričetkov osemnajstega stoletja naprej. Pri tem je šlo za notranjo krizo, ki je zdaleč presegala vse krize, ki so se dotlej izražale $\mathrm{v}$ cikličnih vzponih in padcih posameznih dinastij, in ki je neprimerno globlje posegla v tradicionalno strukturo družbe in države. To pomeni, da bi v

3 Predvsem v svojem delu Jenaer Schriften (1986).

4 Tukaj velja omeniti predvsem osrednja predstavnika kritične teorije, Maxa Horkheimera in Theodorja W. Adorna ter njuno klasično delo Dialektika razsvetljenstva (1947). Sicer pa velja v tem kontekstu poudariti, da so zahodni diskurzi modernizacije večinoma temeljili na absolutistični kritiki razuma in so zato privedli do slepe ulice samoreferenčnosti; zatem so se razvili alternativni teoretski projekti samokritične utemeljitve moderne s pomočjo drugačnega, jezikovno determiniranega razumevanja pojma razuma. Ta lingvistični preobrat je zopet privedel do dveh različnih utemeljitev oziroma izhodišč za razlago moderne. Prvo tako izhodišče se je pokazalo v postmodernem "preseganju« normativnega razumevanja, drugo pa v intersubjektivnem preoblikovanju klasičnega pojma (Habermas 1998, 195). V prevladujočem zahodnem razumevanju torej ne gre zgolj za razlaganje neke specifične družbene situacije, ki se večinoma kaže kot kritika razuma, temveč za takšen uvid v pojmovni spekter moderne, ki vključuje tudi konotacijo "zavestne diskontinuiranosti novega od starega« oziroma modernega od tradicionalnega. 
devetnajstem stoletju tudi v tej državi moralo - celo brez stikov z Zahodom priti do radikalnih sprememb tako na področju ekonomije kot tudi na področju politike, idejnih sistemov in kulture. Zato lahko samo ugibamo, kakšna bi bila Vzhodna Azija dandanes, če njene modernizacije ne bi od zunaj sprožile zahodne kolonialne sile.

Vsega tega pa klasične (beri: zahodne) teorije modernizacije seveda ne upoštevajo. Njihova predpostavka o inferiornosti azijskih kultur ni omejena zgolj na tehnološki vidik, temveč se jasno kaže tudi v njihovem razumevanju vzhodnoazijskih idejnih sistemov. Večina zahodnih teoretikov moderne je namreč izhajala iz predpostavke, po kateri bi morala Vzhodna Azija, če se želi razviti v moderno in dinamično družbo, opustiti konfucijanstvo in druge tradicionalne idejne sisteme. Marx in številni drugi klasični teoretiki modernizacije so izrecno poudarjali, da je konfucijanska kultura popolnoma neprimerna za modernizacijo. Tudi Weber je veliko pisal o Aziji, predvsem o Kitajski in Indiji, ter pri tem poudaril, da te družbe zaradi svojih religij niso primerne za modernizacijo. Izhajajoč iz Webrovega argumenta, da je protestantska etika izjemno koristna za promocijo vzpona in širitve modernizacije, pa se nakaže tudi potreba po kritični raziskavi stališča, ki se je v zadnjih dveh desetletjih razširilo po Vzhodni Aziji in ki zagovarja hipotezo, po kateri naj bi družbe, ki temeljijo na konfucijanski etiki, bolje izpolnjevale pogoje za industrializacijo, izobilje in modernizacijo. Za razjasnitev vprašanja o tem, ali je takšna evrocentrična perspektiva modernosti še vedno veljavna, velja vse zgoraj omenjene predpostavke vsekakor podrobno raziskati, kajti sodobne teorije vzhodnoazijskih raziskovalk in raziskovalcev kažejo na to, da je s pomočjo oživljanja tradicionalnih političnih, družbenih in etičnih konceptov morda mogoče izdelati model drugačne modernizacije, ki ni ustrojena zgolj po kalupih zahodnih družbenih razvojev. Takšni modeli ne temeljijo nujno na poudarjanju individualizma, zato kažejo na dejstvo, da je morda tudi predpostavka o nujni in inherentni povezavi med individualizmom in modernizacijo zgolj produkt zahodnih zgodovinskih in socioloških paradigem.

\section{Izmišljene tradicije in fragmentacija kultur: konfucijanstvo kot alternativa evrocentrizmu?}

Pri vrednotenju poskusov vzpostavitve »specifično vzhodnoazijskih« idejnih osnov modernizacije je pomembno, da jih poskušamo ovrednotiti tudi znotraj konteksta vprašanj, povezanih s predpostavko »izmišljenih tradicij« (»invented traditions«, Hobsbawm in Ranger 1995). Pri tem gre za vprašanja o tem, v kolikšni meri te idejne "tradicije« dejansko temeljijo na zgodovinskih predpostavkah in v kolikšni meri so zgolj proizvod (ideoloških in političnih) zahtev sodobnega časa. 
Upoštevati moramo namreč dejstvo, da je transnacionalizacija kapitala med drugim povzročila tudi univerzalizacijo kapitalističnega načina proizvodnje, ki je s tem postalo oddvojeno od svojega specifičnega zgodovinskega izvora v Evropi. Z drugimi besedami, kot trdi Arif Drilik (1994, 51), se moramo navaditi na dejstvo, da »zgodba kapitalizma ni več samo evropska zgodba«.

Prvič v zgodovini se dogaja, da zahtevajo tudi neevropske kapitalistične družbe pravico do svoje zgodovine kapitalizma. To, kar obstaja vzporedno z ekonomsko in politično fragmentacijo, torej fragmentacija kultur, ki jo, da se lepše sliši, poimenujemo s frazo »multikulturalizem«. Morda se najbolj dramatična plat tega novega kulturnega razvoja $\mathrm{v}$ zadnjih desetletjih kaže v prizadevanjih za to, da bi se kapitalizem v Vzhodni Aziji prilagodil tako imenovanim konfucijanskim vrednotam; pri tem gre torej za tendenco, ki je nasprotna tisti, ki je bila postavljena na predpostavki, češ da predstavlja konfucianizem, zgodovinsko gledano, oviro za razvoj kapitalizma. (Dirlik 1994, 51)

Številni teoretiki so mnenja, da prevlada »multi-kulturalizma« hkrati pomeni tudi konec evrocentrizma. Vendar je pojem multi-kulturalizma zavajajoč, saj prekriva ne zgolj kulturno fragmentacijo, kot trdi Dirlik (ibid.), temveč hkrati v enaki meri izpodkopava tradicionalne oblike proizvodnje in socialnih omrežij. Zato je konec evrocentrizma iluzoren in njegova notranja struktura še vedno ostaja prevladujoči del idejne konstelacije postmodernih, globaliziranih družb:

Menim, da lahko vsekakor trdimo, - in to bom tukaj tudi sam trdil da je domnevni konec evrocentrizma iluzoren. Kapitalistična kultura, kakršna se je izoblikovala $\mathrm{v}$ današnjem svetu, vsebuje evrocentrizem $\mathrm{v}$ srži strukture svojih naracij. To je tudi razlog za dejstvo, da kulturne vrednote Evrope in Amerike še vedno prevladujejo na globalni ravni, čeprav Evropa in ZDA postopoma izgubljata prevlado v kapitalistični svetovni ekonomiji. Poleg tega ne smemo pozabiti, da to, kar omogoča tako imenovani preporod konfucijanstva v Vzhodni Aziji, nikakor ni prizadevanje za to, da bi ta diskurz tej regiji ponudil nekakšne alternativne vrednote, ki bi bile boljše od tistih, ki izvirajo iz Evrope oziroma Amerike. Pri tem gre namreč prej za artikuliranje matičnih kultur v ogrodje kapitalističnih ideologij. Vendar pa moramo kljub temu priznati, da so postale svetovne kulture iz tovrstnih razlogov neprimerno kompleksnejše, kot so bile kulture $\mathrm{v}$ zgodnejših fazah kapitalizma (ibid., 51-52). 
Pri tem niti ne gre toliko za fragmentacijo kultur, temveč bolj za fragmentacijo prostora, ki globalnemu kapitalizmu nudi nove možnosti reševanja starih problemov, povezanih $\mathrm{z}$ maksimiranjem dobička, nadzorovanjem trga in osvobajanja proizvodnje in marketinga izpod pritiskov možnih socialnih intervencij (povezanost delavskih stavk) ali političnega nadzora (državni ukrepi). Ta fragmentacija prostora pa skupaj s prikritim ohranjanjem latentnega evrocentrizma implicira tudi fragmentacijo časovnih dimenzij kapitalizma:

$\mathrm{Z}$ drugimi besedami lahko rečemo, da je izziv evrocentrizmu v tem, da je sedaj mogoče prihodnost snovati na načine, ki so drugačni od tistih, ki so običajni v evro-ameriških modelih. Tukaj postaja ponovno jasno, da je resnično težko razlikovati med resničnostjo in iluzijo; vsekakor so ta vprašanja brezdvomno nadvse kompleksna (ibid., 52).

In ne samo to: fragmentacija prostora implicira tudi razbitost socialnega položaja posameznika, ki se, kot opozarjajo predstavniki modernega konfucijanstva, manifestira v odtujenosti modernega subjekta.

Kot opozarja Dirlik $(2002,18)$, lahko pretirano osredotočanje na evrocentrizem in njegove idejne ter politične konotacije odvrne našo pozornost od te fragmentacije sveta na drugačen, prav tako pomemben način. Modernizacija ima namreč povsod številne in nadvse kompleksne posledice. Zagotovo ni naključje, katere vidike bomo pri tem izbirali kot predmet obravnave. Enodimenzionalna kritika evrocentrizma, njegovega zgodovinopisja in njegovega strukturiranja sveta pri tem ne zadošča. V svojem najširšem pomenu, torej vključujoč tudi vsakodnevne življenjske prakse, evrocentrizem že dolgo ni več zgolj stvar Evrope, temveč pojav globalne modernosti; izzivi evrocentrizma zato vplivajo tudi na tiste ne-evropske družbe, ki so modernizacijo že zdavnaj sprejele kot svoje vodilno načelo. $V$ tem smislu sodijo teorije modernih konfucijancev druge generacije v kontekst "preporoda kitajske zgodovine«, ki v brzicah eksplozivno »vsiljene« modernizacije sploh ni prišla do besede. Vse to se lepo sklada $\mathrm{z}$ aktualno »reinkarnacijo « teorij modernosti (ibid., 20), ki išče možnosti absorbiranja multikulturnih, alternativnih obrazov modernizacije. Ta odvrnitev od evrocentrizma, ki je bila v kolonializmu (in pred njim) lastna klasičnim teorijam modernizacije, pa je zgolj navidezna, saj se dogaja na skupni osnovi globaliziranega kapitalizma. Po Dirliku je v tej fazi globalnega razvoja popolnoma samoumevno in celo potrebno, da se $\mathrm{v}$ diskurze modernizacije vključijo tudi vse prej omalovaževane »kulturne inačice« modernizacije, ki so bile poprej razglašene za njene »ovire«. Inkorporacija in ponotranjenje različnih »repertoarjev modernizacije« (vključno z njihovimi specifičnimi vrednotami ter mehanizmi proizvodnje in potrošništva) v ekonomske prakse sodobnega globalnega 
sistema potemtakem služi tudi kot gonilna sila univerzalizacije institucionalnih struktur, ki so nujne za njegovo delovanje.

Vse to lepo sovpada z novimi, post-modernimi koncepti, h kakršnim sodi, denimo, koncept »razvnorstnih modernosti« (multiple modernities) Shmuela Noaha Eisenstadta. Četudi je vzpostavitev tega koncepta utemeljena na tezi, po kateri modernizacija ne-evropskih družb ni enaka njihovemu pozahodnjenju (Eistenstadt 2000,2-3), je njegova teorija v svojem bistvu konservativna, saj svoje interpretacije različnih oblik modernizacije in modernosti postavlja v kontekst afirmacije globalnih razmerij oblasti, pri čemer njene različne modele umešča v okvire različnih držav, narodov in »kultur«, ki so videne kot njihova razločevalna posebnost.

To, česar ideja raznovrstnih modernosti ne upošteva, je dejstvo, da je preporod zgodovine lasten tako narodom kot tudi civilizacijam. Vprašanje modernosti je predmet debate $\mathrm{v}$ različnih prostorih kultur, civilizacij, narodnosti in etničnosti, saj vsi ti prostori v enaki meri predstavljajo enote analize. To je seveda legitimno, dokler gledamo na to vprašanje $z$ globalne perspektive, in vendar se njegova slika popolnoma spremeni, če se nanjo ozremo s posamičnih lokalnih perspektiv. Problemi evrocentrizma, ki predstavlja osnovo kapitalizma in dinamično silo znotraj njega, ter problemi modernosti, ki so z njim povezani, nikakor niso zgolj problemi razlik med narodi in civilizacijami, temveč so vraščeni v samo srž njihovih konstitucij (Dirlik 2001, 26).

\section{Zaključek}

Razlike med sedanjostjo in preteklostjo $\mathrm{v}$ prvi vrsti ne gre iskati v izzivih evrocentrizma, ki jih predstavljajo različne kulturne perspektive, temveč v priznavanju dejstva, da je klasični model modernizacije na globalni ravni privedel do situacije, v kateri problemi, ki jih prinaša, niso več zgolj problemi t. i. ne-evropskih, temveč tudi problemi evro-ameriških družb. Potreba po spoznavanju »alternativnih modernosti« predstavlja torej izziv tudi za evro-ameriške kulture modernizacij, saj na novo vzpostavlja njihove meje oziroma jih na novo lokalizira, s čimer vzpostavlja koncept modernosti kot take, ki pa ni nujno zgolj univerzalna, temveč je hkrati tudi kulturno pogojena.

Eno pomembnih nalog vzhodnoazijskih študij je zato najti tudi v poskusih razkritja posebnega rezervoarja vrednot in znanj, ki lahko nedvomno predstavljajo obogatitev naših predpostavk o različnosti tradicij in modernosti. A pri tem nikakor ne smemo pozabiti, da živimo v obdobju, ki ni določeno samo s poskusi oživitev 
različnih tradicij, temveč tudi s poskusi njihovega usklajevanja s potrebami prevladujočih ekonomskih, političnih in aksioloških struktur globalnega sveta. Ne glede na različne despotske anomalije lahko namreč trdimo, da vzhodnoazijske tradicije konec koncev temelje na komunitarizmu, katerega temeljni dejavnik je solidarnost znotraj skupnosti. Komunitarizem kot struktura razmerja med posameznikom in skupnostjo pa lahko nudi etične alternative prevladujočim pogojem globalnega kapitalizma, ki v veliki meri temelje na nebrzdani gonji za dobičkom in na mehanizmih samodinamike ekonomije svobodnega trga. Tovrstne etične alternative, ki jih lahko najdemo v vzhodnoazijskih tradicijah, predstavljajo pomemben vidik sodobnega humanizma in s tem humanistike, kamor po svojem bistvu sodijo tudi vzhodnoazijske študije.

\section{Viri in literatura}

Adorno, Theodor W. in Max Horkheimer. 1947. Dialektik der Aufklärung. Philosophische Fragmente. Amsterdam: Querido Verlag.

Dessein, Bart 2016. "Progress and Free Will: On the Buddhist Concept of 'Time' and Its Possibilities for Modernity." Asian Studies 4 (1): 11-33.

Dirlik, Arif. 1994. After the Revolution: Working to Global Capitalism. Hanover, London: Wesleyan University Press.

—. 2001. "Postmodernism and Chinese History." Boundary 4 (28): 19-60.

- 2002. "Modernity as History: Post-Revolutionary China, Globalization and the Question of Modernity." Social History 27 (1): 16-39.

Eisenstadt, Shmuel Noah. 2000. "Multiple Modernities." Daedalus 129 (1): $1-29$.

Habermas, Jürgen. 1998. Die postnationale Konstellation - Politische Essays. Frankfurt/Main: Suhrkamp.

Hegel, Georg Wilhelm Friedrich. 1986. Jenaer Schriften. Frankfurt/Main: Suhrkamp.

Hobsbawm, Eric in Terence Ranger, ur. 1995. The Invention of Tradition. Cambridge and New York: Cambridge University Press.

Lukàcs, György. 1986. Zgodovina in razredna zavest: študije o marksistični dialektiki Ljubljana: Inštitut za marksistične študije ZRC SAZU.

Marx, Karl. 2012. Ökonomisch philosophische Mauskripte. Reihe marxistischer Klassiker. Internationale Sozialisten. Dostop 17. januar, 2016. http://www. mlwerke.de/ies/ueber.htm.

Rošker, Jana S. 2006 Na ozki brvi razumevanja - metodologija medkulturnib raziskav v sinoloških študijah. Ljubljana: Oddelek za azijske in afriške študije, Filozofska fakulteta Univerze v Ljubljani. 
Weber, Max. 1989. Die Wirtschaftsethik der Weltreligionen Konfuzianismus und Taoismus. Tübingen: J. C. B. Mohr (Paul Siebek).

Zhang, Dainian 張岱年. 2003. Zhongguo zhexue shi fangfalun fa fan 中國哲學史 方法論發凡. Beijing: Zhonghua shuju.

\section{Summary}

The article explores and introduces some of the central problems linked to research in the field of Asian studies. The author first clarifies why it is important to approach these areas through the native languages and their own texts. This approach is of key importance, for it is the only way to overcome the absolute dichotomy between the active research subject and passive research object. The use of primary sources provides insights into the structure of issues and interpretations that are characteristic of the socialization process, as well as the contents and methodological approaches that form the research subjects. The author also shows how and why intercultural research necessarily involves translation. However, this translation cannot be limited to a linguistic transfer, but must include the interpretation of specific textual/speech structures, categories, concepts and values existing in diverse socio-cultural contexts. In recent years, there has been a growing demand to revive the classic categories and concepts belonging to traditional East Asian theoretical discourses. Proceeding from and taking into account these problems, the author investigates in the second part of the article the universal and culturally conditioned elements in the process of modernization, particularly referring to the relation between tradition and modernity in East Asia. 